\title{
HUBUNGAN ANTARA TINGKAT PENGGUNAAN WHATSAPP DENGAN DERAJAT KOHESIVITAS PADA KELOMPOK TANI PEDESAAN
}

\section{The Relationship Between Whatsapp Usage Level with Rural Farmer Group Cohesiveness Degree}

\author{
Sari Rahayu Rezeki*) dan Ir. Hadiyanto
}

Departemen Komunikasi dan Pengembangan Masyarakat, Fakultas Ekologi Manusia, IPB

*)E-mail: sarirezeki25@gmail.com

Diterima: 23-10-21 | Disetujui: 19-01-22 | Publikasi online: 19-01-22

\begin{abstract}
This research is motivated by technological developments that are increasingly advancing and developing day by day. As technology advances, social media also grows and develops rapidly. Whatsapp is one of the social media that is widely used. Bunga Desa II Farmer Group uses whatsapp as a communication medium within the farmer group. Through whatsapp application, farmer group members can discuss and cooperate with each other. This study aims to analyze the relationship between respondents' characteristics and analyze the relationship between the use of whatsapp social media and the cohesiveness of Desa Desa II Group which is located in Sukaharja Village, Cijeruk District, Bogor Regency. Respondent subjects in this study were 30 people who were members of the whatsapp group of farmer groups. Data collection tools used were questionnaires and in-depth interview methods. The results showed that in the use of whatsapp as seen from the frequency, duration, and attention, only the attention of whatsapp usage was significantly related to the farmer group cohesiveness degree.
\end{abstract}

Keywords: Cohesiveness, Farmer groups, Social media, Whatsapp

\section{ABSTRAK}

Penelitian ini dilatarbelakangi oleh perkembangan teknologi yang semakin hari semakin maju dan berkembang. Saat teknologi semakin maju, media sosial juga ikut tumbuh dan berkembang pesat. Whatsapp menjadi salah satu media sosial yang paling banyak digunakan. Kelompok Tani Bunga Desa II menggunakan whatsapp sebagai media komunikasi di dalam kelompok tani. Melalui aplikasi whatsapp, anggota kelompok tani dapat saling berdiskusi dan bekerja sama. Penelitian ini bertujuan untuk menganalisis hubungan karakteristik responden dan menganalisis hubungan penggunaan media sosial whatsapp dengan kohesivitas Kelompok Tani Bunga Desa II yang terletak di Desa Sukaharja, Kecamatan Cijeruk, Kabupaten Bogor. Subjek responden pada penelitian ini adalah 30 orang yang tergabung dalam anggota group whatsapp kelompok tani. Alat pengumpulan data yang digunakan adalah kuesioner dan metode wawancara mendalam. Hasil penelitian menunjukkan bahwa pada penggunaan whatsapp yang dilihat dari frekuensi, durasi, dan atensi, hanya atensi penggunaan whatsapp saja yang berhubungan nyata dengan derajat kohesivitas pada kelompok tani.

Kata kunci: Kelompok tani, Kohesivitas, Media sosial, Whatsapp 



\section{PENDAHULUAN \\ Latar Belakang}

Berdasarkan data yang di dapat dari Badan Pusat Statistik (BPS) Februari 2018, terdapat 38.700 .530 orang penduduk Indonesia yang bekerja pada sektor pertanian secara luas, lalu diikuti oleh penduduk yang bekerja di sektor perdagangan dan industri. Begitu juga dengan penduduk di pedesaan yang mayoritas masih bermata pencaharian sebagai petani. Di Kabupaten Bogor, jumlah penduduk yang bekerja pada bidang pertanian meliputi tanaman pangan, hortikultura, peternakan, perkebunan, kehutanan, dan perikanan mencapai 203.393 orang.

Sesuai dengan Peraturan Menteri Pertanian No. 82 tahun 2013 tentang Pedoman Pembinaan Kelompok Tani dan Gabungan Kelompok Tani, Kelompok tani berfungsi untuk memfasilitasi kegiatan-kegiatan usaha bersama mulai dari sektor hulu sampai hilir secara komersial dan berorientasi pasar, dimana setiap kelompok tani dapat memberikan pelayanan informasi, teknologi dan permodalan kepada anggota kelompoknya serta menjalin kerjasama dengan pihak lain. Berdasarkan hal tersebut, media sosial dapat dijadikan alternatif pilihan sebagai sarana penyebaran informasi dan komunikasi di dalam kelompok tani.

Terdapat berbagai jenis media sosial salah satunya adalah whatsapp. Pada saat ini, whatsapp menjadi salah satu media sosial yang paling banyak digunakan. Menurut survei We Are Social (2019) terkait pemanfaatan media sosial di Indonesia, youtube menempati urutan pertama dengan jumlah pengguna sebesar $88 \%$, disusul whatsapp sebesar $83 \%$, selanjutnya facebook sebesar $81 \%$, kemudian instagram $80 \%$, line 59\%, dan twitter 52\%. Di Indonesia sendiri whatsapp merupakan salah satu media sosial yang populer karena kemudahan dalam penggunaannya dibandingkan dengan media sosial lainnya. Whatsapp merupakan sebuah aplikasi media sosial yang dirancang untuk memudahkan penggunanya dalam berkomunikasi melalui berbagai macam fitur yang tersedia. Beberapa fitur yang ada pada aplikasi whatsapp antara lain chat group, panggilan suara dan video, enskripsi end-to-end, pengiriman foto dan video, pesan suara, dan dokumen. Maka dari itu banyak masyarakat yang memilih whatsapp sebagai media komunikasi, begitu pula dengan para petani dan kelompok tani.

Menurut Yuvaraj (2012), media sosial whtasapp dapat dimanfaatkan untuk pengembangan pertanian. Melalui media sosial whatsapp, dapat terjadi pertukaran informasi dan komunikasi antar petani, kelompok tani dan gabungan kelompok tani. Komunikasi di dalam kelompok sendiri memiliki fungsi untuk menjaga kohesivitas serta mempertahankan eksistensi dan kepaduan kelompok. Anggota kelompok diharapkan menghimpun komunikasi yang baik dan mengoptimalkan kemampuannya untuk turut serta memberi kontribusi demi kelangsungan kelompok. Hal ini diperkuat oleh hasil penelitian Wulansari et al. (2013) yang menyebutkan bahwa ada hubungan yang signifikan antara komunikasi yang efektif dengan kohesivitas kelompok. Kohesivitas sangat penting bagi kelompok tani karena menyangkut beragam anggota yang menjadi satu kesatuan. Adanya kepuasan yang didapat dari anggota dalam kelompok tani membuat anggota tersebut merasa nyaman untuk bertahan dalam kelompok, sehingga kebutuhan mereka dapat terpenuhi. Kohesivitas dalam kelompok tani membuat anggota akan bersedia melakukan kegiatan yang ada di dalam kelompok. Selain hal tersebut, masing-masing anggota merasa bebas untuk mengemukakan pendapat dan saran.

Meskipun pada saat ini komunikasi di dalam kelompok tani telah dilakukan menggunakan teknologi whatsapp, ternyata terdapat beberapa permasalahan yang terjadi. Anggota yang tidak memiliki data internet contohnya, mereka akan mengalami kesulitan untuk berkomunikasi dengan group kelompok tani. Selain itu, bagi anggota yang kurang aktif dalam menggunakan aplikasi media sosial whatsapp juga mengalami kesulitan karena banyak kehilangan informasi terkait kelompok tani. Bahkan ketika diskusi di dalam group kelompok tani sedang berlangsung, banyak anggota kelompok yang pasif sehingga diskusi menjadi kurang maksimal. Permasalahan komunikasi ini dapat menjadi pemicu kesalahpahaman dan konflik antar anggota dalam kelompok, sehingga dapat mengganggu hubungan antar anggota yang berdampak pada kebersamaan dan rasa 
saling memiliki dalam kelompok tani. Dampak dari permasalahan-permasalahan tersebut adalah rendahnya perasaan untuk tetap bertahan di dalam

kelompok atau disebut kohesivitas kelompok. Selain hal tersebut, rendahnya kohesivitas kelompok pada kelompok tani juga membuat beberapa kelompok tani tidak dapat bertahan lama karena kehilangan anggotanya.

Salah satu kelompok tani yang sudah menggunakan media sosial whatsapp sebagai sarana komunikasi di dalam kelompok yaitu Kelompok Tani Bunga Desa II, Desa Sukaharja, Kecamatan Cijeruk, Kabupaten Bogor, Jawa Barat. Media sosial whatsapp dipilih kelompok tani karena dirasa lebih mudah dan cepat dalam penggunaannya. Hal ini menjadi menarik untuk diteliti melihat media sosial whatsapp kini menjadi kebutuhan bagi seluruh masyarakat Indonesia, namun pada penerapannya belum tentu media sosial ini dapat dimanfaatkan sebagai sarana komunikasi yang efektif dan berhubungan dengan terbentuknya kohesivitas di dalam kelompok. Berdasarkan kondisi tersebut menjadi menarik untuk dikaji mengenai bagaimana hubungan antara tingkat penggunaan whatsapp dengan derajat kohesivitas kelompok tani di pedesaan?

\section{Rumusan Masalah}

Berdasarkan latar belakang di atas rumusan masalah dalam penelitian ini adalah sebagai berikut: (1) Bagaimana hubungan antara karakteristik individu kelompok tani dengan tingkat penggunaan whatsapp sebagai media penyebaran informasi di dalam kelompok tani pedesaan?; dan (2) Bagaimana hubungan tingkat penggunaan whatsapp dengan derajat kohesivitas kelompok tani pedesaan?

\section{Tujuan Penelitian}

Berdasarkan pemaparan rumusan masalah di atas, tujuan penelitian ini adalah sebagai berikut: (1) Menganalisis hubungan antara karakteristik individu dengan tingkat penggunaan whatsapp sebagai media penyebaran informasi di dalam kelompok tani pedesaan; dan (2) Menganalisis hubungan antara penggunaan media sosial whatsapp dengan derajat kohesivitas kelompok tani pedesaan.

\section{Manfaat Penelitian}

(1) Bagi akademisi, hasil penelitian ini mampu memberikan informasi mengenai pemanfaatan media sosial whatsapp sebagai media penyebaran informasi pertanian dan juga dapat dijadikan referensi untuk penelitian selanjutnya; (2) Bagi Kelompok Tani Bunga Desa II, penelitian ini diharapkan dapat memberi gambaran mengenai hal-hal apa saja yang harus ditingkatkan dalam diri anggota kelompok tani agar dapat meningkatkan kekompakan kelompok serta berusaha dan bekerja sama lebih baik lagi; dan (3) Bagi masyarakat, penelitian ini diharapkan dapat memberikan gambaran yang positif kepada masyarakat yang ada di sekitar agar mempunyai keinginan untuk hidup berkelompok atau berorganisasi karena adanya manfaat yang dapat dihasilkan dibandingkan dengan berusaha secara sendiri-sendiri.

\section{PENDEKATAN TEORITIS}

\section{Karakteristik Individu Petani}

Menurut UU No. 2 Tahun 1960, petani ialah orang, baik yang mempunyai maupun tidak mempunyai tanah yang mata pencaharian pokoknya adalah mengusahakan tanah untuk pertanian. Ciri-ciri atau sifat yang dimiliki seorang petani meliputi beberapa faktor atau unsur-unsur yang melekat pada diri seseorang yang dapat dikatakan sebagai karakteristik petani. Karakteristik petani adalah ciri-ciri atau sifat yang dimiliki oleh seseorang petani yang ditampilkan melalui pola pikir, pola sikap dan pola tindakan terhadap lingkungannya (Mislini 2006). Pada penelitian Sulistiawati et al. (2014), terdapat beberapa hal yang dapat mempengaruhi perilaku seorang anggota kelompok tani dalam berkomunikasi, yaitu: usia, tingkat pendidikan, skala usaha, pengalaman usaha.

\section{Kelompok Tani}

Menurut Beebe dan Masterson (1994), seseorang bergabung ke dalam suatu kelompok karena adanya lima dimensi, yaitu: (1) Kebutuhan pribadi (interpersonal needs): kebutuhan pribadi 
seseorang dapat dikaitkan dengan hierarki kebutuhan menurut Maslow yaitu dimulai dari kebutuhan fisiologis, kebutuhan rasa aman, kebutuhan rasa memiliki, kebutuhan untuk dihargai, dan kebutuhan aktualisasi diri.

(1) Tujuan individual (individual goals): merupakan alasan mengapa individu bergabung dalam suatu kelompok yang berkenaan dengan minat dalam dirinya untuk meningkatkan kemampuan mereka; (2) Tujuan kelompok (group goals): merupakan tujuan yang dapat diidentifikasi melampaui tujuan individual. Tujuan ini berkembang sebagai tujuan bersama yang meliputi tujuan individual masing-masing anggota; (3) Daya tarik interpersonal (interpersonal attraction): sebagian orang tertarik bergabung dalam sebuah kelompok karena mereka tertarik dengan orangorang yang ada di dalamnya yang meliputi komponen kesamaan, saling melengkapi, kedekatan, dan daya tarik fisik; dan (4) Daya tarik kelompok (group attraction): ketika seseorang bergabung dalam sebuah kelompok karena tertarik dengan anggota di dalamnya, mereka juga mungkin tertarik dengan kelompok itu sendiri, yang meliputi aktivitas kelompok, tujuan, dan kesederhanaan dalam penerimaan anggota.

Kelompok tani merupakan sebuah kelembagaan ditingkat petani yang dibentuk untuk mengorganisir para petani dalam berusaha tani. Sesuai dengan SK Menteri Pertanian No. 93/Kpts/OT. 210/3/97 tanggal 18 Maret 1997, kelompok tani merupakan kumpulan dari petani yang tumbuh berdasarkan keakraban dan keserasian, serta adanya kesamaan kepentingan dalam memanfaatkan sumber daya pertanian untuk bekerja sama dalam meningkatkan produktivitas usaha tani dan kesejahteraan dari para anggotanya. Benu et al. (2016) mengatakan bahwa pembentukkan kelompok tani merupakan suatu usaha pembangunan pertanian yang berfungsi untuk memperlancar hasil pertanian dan memberikan wadah yang kokoh di pedesaan dan merupakan tempat untuk memperkuat kerjasama diantara para petani dalam kelompok untuk menghadapi berbagai ancaman, tantangan, hambatan dan gangguan.

\section{Media Sosial}

Menurut Nasrullah (2016) dalam Sukrillah et al. (2017) Karakteristik yang dimiliki media sosial diantaranya: 1) Jaringan (network). Media sosial memiliki karakter jaringan sosial; 2) Informasi (information). Informasi menjadi entitas yang penting dari media sosial; 3) Arsip (archive). Arsip mengubah cara menghasilkan, mengakses, hingga menaruh informasi; 4) Interaksi (interactivity). Pengguna bisa berinteraksi, baik di antara pengguna itu sendiri maupun dengan produser konten media; 5) Simulasi sosial (simulation of society). Pengguna media sosial bisa dikatakan sebagai warga negara digital; dan 6) Konten oleh pengguna (user-generated content). Konten sepenuhnya milik dan berdasarkan kontribusi pengguna atau pemilik akun.

Media komunikasi juga dapat digunakan dalam mendiseminasikan informasi pertanian dan media edukasi bagi petani. Kemajuan TIK (Teknologi Informasi dan Komunikasi) berpotensi menjadi peluang yang besar bagi pelaku pembangunan pertanian. Munculnya kehadiran media internet ini juga berdampak pada tumbuhnya media sosial lain diantaranya: LINE, Facebook, Whatsapp, Instagram, dll. Data terbaru dari Google Consumer Behaviour yang dituliskan APJII (2018) menyatakan bahwa Indonesia yang total populasinya 265,4 juta memiliki $50 \%$ pengguna internet. Indonesia menempati posisi keenam pengguna internet terbanyak di dunia. Hidayat (2014) menjelaskan bahwa angka tersebut mendudukkan Indonesia di peringkat ke-6 terbesar di antara sekitar 3,6 miliar jumlah pengakses internet dunia.

Sebagai alat komunikasi, hadirnya media sosial dapat menimbulkan dampak yang besar bagi kehidupan masyarakat. Selain manfaat fungsional yang diperoleh dari penggunaan media sosial, penelitian Ratnasari (2007) menunjukkan bahwa media sosial juga memiliki efek disfungsional. Internet juga dapat menyebabkan penggunanya mengalami kecanduan. Rasa senang yang diperoleh dari berinternet menyebabkan seseorang lupa waktu, sehingga menimbulkan ketergantungan yang mendatangkan masalah. Hasil-hasil penelitian tersebut berusaha untuk memperlihatkan bahwakehadiran teknologi komunikasi baru, khususnya media sosial yang saat ini telah demikian menyebar di lingkungan masyarakat tidak terlepas dari manfaat yang positif dan dampak buruknya. 
Media sosial merupakan media yang berpengaruh besar pada perkembangan interaksi dan di dunia maya sehubungan dengan beragamnya jenis, fasilitas, dan teknologi yang ada pada media sosial ini. Hal ini disebabkan karena media sosial tidak hanya menekankan pada aspek terjadinya hubungan atau konektivitas (connectivity) semata tetapi juga interaktivitas (interactivity). Sifat connectivity dan interactivity yang dimiliki media sosial ini kemudian mendorong terjadinya beragam interaksi para penggunanya.

\section{Whatsapp Sebagai Media Komunikasi Kelompok}

Whatsapp sebagai salah satu media sosial saat ini banyak digunakan untuk kepentingan bersosialisasi dan penyampaian pesan baik oleh individu atau kelompok. Whatsapp merupakan media sosial yang memiliki tampilan sederhana dan mudah digunakan sehingga diminati oleh semua kalangan. Whatsapp tidak menggunakan pulsa seperti Short Message Service (SMS) melainkan whatsapp menggunakan data internet. Dikutip dari Detiknet "Pengguna whatsapp sebagai pesan instant terpopuler didunia telah mecapai 1 milliar pengguna aktif setiap harinya, ratarata 1,3 milliar pengguna pengguna aktif menggunakan whatssap tiap bulan, dari 55 milliar pesan, 4,5 milliar diantaranya berupa foto, sementara 1 milliar adalah video, mayoritas pesan berupa tulisan, sedangkan di Indonesia pengguna whatssapp mencapai angka 58\%" (Yudhianto 2017).

Dalam laman resmi Whatsapp di dalam Appstore (Whatsapp inc 2018), dijelaskan fitur-fitur yang dimiliki dan keuntungan menggunakan layanan Whatsapp yaitu: (1) Tanpa biaya tambahan: watsapp menggunakan koneksi internet telepon (4G/3G/2G/EDGE atau Wi-Fi, jika tersedia) untuk mengirim pesan dan menelepon pengguna lain, sehingga tidak perlu digunakan biaya tambahan untuk setiap pesan atau panggilan kecuali biaya untuk sambungan internet; (2) Multimedia: Kemampuan multimedia untuk mengirim dan menerima foto, video, dokumen, dan pesan suara; (3) Panggilan Whatsapp: Panggilan gratis yang dapat dimanfaatkan pengguna untuk menelpon pengguna lain secara gratis bahkan untuk panggilan antar negara; (4) Group Chat atau Obrolan Grup: yang memungkinkan pengguna melakukan percakapan grup dengan beberapa kontak-kontak whatsapp sehingga dapat dengan mudah menjalin komunikasi dengan beberapa pengguna sekaligus; (5) Whatsapp Web: dapat mengirim dan menerima pesan whatsapp secara langsung dari browser atau peramban computer; (6) Tanpa biaya Internasional: Tidak ada biaya tambahan untuk mengirim pesan whatsapp internasional; dan (7) Tidak adanya username dan PIN: Tidak diperlukan kode pin karena whatsspp bekerja persis seperti SMS dengan menggunakan nomor telepon dan terintegrasi dengan buku alamat pada telepon. Berdasarkan uraian mengenai layanan whatsapp dan fitur-fitur yang dimilikinya, dapat diketahui bahwa aplikasi layanan whatsapp menyediakan layanan pesan instan yang berjalan pada beberapa platfrom seperti Android, iOS, dan Windows yang memungkinkan penggunanya untuk saling mengirim pesan, gambar, video, dokumen, dan sebagainya dengan jangkauan internasional tanpa dibebani biaya tambahan melainkan menggunakan sambungan internet. Tidak jarang sebuah intansi, organisasi, dan perusahaan turut memanfaatkan kehadiran dari aplikasi ini.

\section{Kohesivitas Kelompok}

Tingkatan yang menunjukkan anggota kelompok saling terkait satu sama lain menunjuk pada kohesivitas (kekompakan) kelompok. Di samping kualitas komunikasi, jumlah komunikasi juga dapat mempengaruhi kohesivitas kelompok. Komunikasi yang bebas dan terbuka mencirikan kelompok yang kohesif (Beebe dan Masterson 1994). Menurut Robbins (1999), setiap kelompok mempunyai tingkat kohesivitas yang berbeda-beda, tergantung dari sejauh mana anggota merasa tertarik satu sama lain dan termotivasi untuk tetap berada dalam kelompok tersebut. Berbagai hasil studi sebelumnya menunjukkan bahwa semakin kompak suatu kelompok, maka anggota akan mengarah pada tujuan-tujuan kelompok. Menurut Baron dan Byrne (2003) kohesivitas (cohesiveness) didefinisikan sebagai derajat ketertarikan yang dirasa oleh individu terhadap suatu kelompok. Kohesivitas sangat erat hubungannya dengan konformitas (bertingkah laku dengan caracara yang dipandang wajar atau dapat diterima oleh kelompok atau masyarakat). Salah satu cara untuk diterima oleh orang-orang dalam kelompok adalah dengan dengan menjadi seperti mereka dalam berbagai hal. Pendapat Festinger dkk seperti yang diungkapkan oleh Baron dan Byrne (2003) 
melihat kohesivitas (cohesiveness) sebagai semua kekuatan (faktor-faktor) yang menyebabkan anggota bertahan dalam kelompok, seperti kesukaan pada anggota lain dalam kelompok dan keinginan untuk menjaga atau meningkatkan status dengan menjadi anggota dari kelompok yang tepat.

McDavid dan Hariri dalam Rakhmat (2009) berpendapat bahwa kohesivitas dapat diukur berdasarkan tiga hal, yaitu adanya ketertarikan antar anggota secara interpersonal, ketertarkan anggota pada kegiatan dan fungsi komunitas, dan sejauh mana anggota tertarik pada komunitas sebagai alat untuk memuaskan kebutuhan personalnya. Forsyth dalam Noorlam (2015) menjelaskan bahwa dalam pembentukan sebuah komunitas dibutuhkan beberapa komponen, diantaranya social cohesion, task cohesion, perceive cohesion, dan emotional cohesion.

Menurut Munandar (2001), beberapa faktor yang mempengaruhi kohesivitas kelompok adalah lamanya waktu berada bersama dalam kelompok. Makin lama berada bersama dalam kelompok, makin saling mengenal, makin dapat timbul sikap toleran terhadap orang lain. Dapat ditemukan atau bahkan dikembangkan minat baru yang sama; Penerimaan di masa awal. Maksudnya semakin sulit seseorang diterima di dalam kelompok sebagai anggota, makin lekat atau kohesif kelompoknya. Pada awal masuk biasanya para anggota kelompok yang lama menguji anggota baru dengan cara-cara yang khas oleh kelompoknya; Ukuran kelompok. Makin besar kelompoknya makin sulit terjadi interaksi yang intensif antar para anggotanya sehingga makin kurang kohesif kelompoknya, sebaliknya ukuran kelompok yang kecil memudahkan interaksi yang tinggi; Ancaman eksternal. Kebanyakan penelitian menunjang hasil bahwa kelekatan kelompok akan bertambah jika kelompok mendapat ancaman dari luar; Produktivitas kelompok. Kelompok yang erat hubungannya akan lebih produktif daripada kelompok yang kurang lekat hubungannya.

\section{Hubungan Antara Tingkat Penggunaan Whatsapp dengan Kohesivitas Kelompok Tani Pedesaan}

Media sosial merupakan media yang memiliki pengaruh terhadap perkembangan interaksi di dunia maya sehubungan dengan beragamnya jenis, fasilitas, dan teknologi yang ada pada media sosial ini. Hal ini disebabkan karena media sosial tidak hanya menekankan pada aspek terjadinya hubungan atau konektivitas (connectivity) semata tetapi juga interaktivitas (interactivity). Sifat connectivity dan interactivity yang dimiliki media sosial ini kemudian mendorong terjadinya beragam interaksi para penggunanya, termasuk membentuk komunitas virtual di media sosial tersebut. Jenis. Terdapat berbagai jenis media sosial diantaranya Line, Instragram, Path, Snapchat, Facebook, dan Whatsapp.

Teknologi komunikasi dan informasi yang semakin berkembang saat ini, dapat dijadikan alternatif yang tepat bagi para petani sebagai media untuk berkomunikasi. Penelitian Ardiyanto dan Erdinaya (2005) menunjukkan bahwa dalam penggunaannya media sosial dapat diukur melalui frekuensi, durasi, dan atensi. Frekuensi dalam penelitian ini adalah banyaknya penggunaan media sosial whatsapp oleh anggota kelompok tani dalam satu hari. Durasi adalah penggunaan media dengan mengukur seberapa lama anggota kelompok tani menggunakan media sosial whatsapp dalam satuan jam perhari. Sedangkan, hubungan antara khalayak dengan isi media meliputi attention atau perhatian.

Penelitian ini membahas mengenai bagaimana tingkat penggunaan media sosial Whatsapp dengan kohesivitas di dalam Kelompok Tani Bunga Desa II, Desa Sukaharja, Kecamatan Cijeruk, Kabupaten Bogor. Pada pemanfaatan media sosial tentunya tidak lepas dari pengaruh karakteristik individu. Penelitian Sulistiawati et al. (2014) menunjukkan bahwa terdapat beberapa hal yang dapat mempengaruhi perilaku seorang anggota kelompok tani dalam berkomunikasi, diantaranya: usia, tingkat pendidikan, skala usaha, pengalaman usaha dan motivasi. Karakteristik tersebut diduga berhubungan nyata dengan penggunaan media sosial yang dapat dilihat dari frekuensi, durasi, dan atensi. Dengan karakterisik individu yang berbeda-beda maka dapat menghasilkan penggunaan media sosial yang berbeda-beda juga. Penggunaan media sosial Whatsapp ini selanjutnya berhubungan dengan tingkat kohesivitas kelompok tani. Anggota kelompok tani kini tidak perlu lagi bertemu secara langsung jika ingin menanyakan sesuatu atau sekedar memberi kabar, cukup 
dengan menggunakan fasilitas yang ada di dalam media sosial, seperti chatting, berbagi gambar dan audio. Hal ini membuat anggota kelompok tani dapat terus terhubung antara satu dengan yang lainnya dan dapat menciptakan kohesivitas di dalam kelompok.

\section{PENDEKATAN LAPANG}

\section{Pendekatan dan Metode Penelitian}

Penelitian ini menggunakan metode kuantitatif yang didukung dengan data kualitatif untuk melihat hubungan antar variabel. Metode kuantitatif yang digunakan yaitu dengan metode sensus dengan mengambil semua sampel responden dari suatu populasi. Data kualitatif didapatkan melalui teknik wawancara mendalam kepada informan dan beberapa responden secara langsung. Metode kuantitatif dengan data kualitatif dikombinasikan dalam upaya memperkaya data pada penelitian ini. Kedua metode tersebut dilakukan untuk mendapatkan data primer, sedangkan data sekunder dalam penelitian ini didapatkan dari literatur dan data yang terkait dan relevan dengan topik penelitian ini.

\section{Lokasi dan Waktu Penelitian}

Penelitian mengenai hubungan tingkat penggunaan whatsapp dengan kohesivitas kelompok tani pedesaan ini akan dilakukan di Kelompok Tani Bunga Desa II, Desa Sukaharja, Kecamatan Cijeruk, Kabupaten Bogor. Pemilihan lokasi dilakukan secara sengaja (purposive) dengan mempertimbangkan: (1) Kelompok Tani Bunga Desa II merupakan kelompok tani yang masih aktif dari tahun 2014 hingga saat ini dan bergerak di bidang pertanian tanaman hias; (2) Kelompok Tani Bunga Desa II menggunakan group masangger whatsapp sebagai salah satu media penyebaran informasi pertanian dengan para anggotanya; dan (3) Kelompok Tani Bunga Desa II memiliki jumlah anggota yang mencukupi untuk dilakukan penelitian.

\section{Jenis Data dan Teknik Pengumpulan}

Data yang dikumpulkan dalam penelitian ini terdiri dari data primer dan data sekunder. Data primer diperoleh langsung di lapangan dengan cara observasi, dan wawancara mendalam yang dilakukan kepada informan maupun responden dengan mangacu pada panduan pertanyaan dan kuesioner. Kuesioner sebagai alat ukur yang digunakan dalam penelitian ini diujikan terlebih dahulu untuk mengetahui seberapa baik hasil pengukuran dilapangan dilihat dari validitas dan reliabilitas. Terdapat beberapa langkah yang dilakukan untuk melakukan tes validitas yaitu (1) mendefinisikan secara operasional konsep yang diukur; (2) melakukan uji coba skala pengukuran yang telah disusun sebelumnya kepada sejumlah responden; (3) mempersiapkan tabel tabulasi jawaban; dan (4) menghitung korelasi antara masing-masing peryataan dengan skor total. Setelah diketahui bagaimana hasilnya, ketidaksesuaian pada kuesioner diperbaiki agar lebih valid. Pada penelitian ini uji validitas kuesioner dilakukan dengan ketentuan nilai alfa $>0.10$, serta diuji reliabilitasnya sebagai instrumen pengumpul data kuantitatif minimal 10 kuesioner kepada anggota kelompok tani yang berbeda dan dengan karakteristik anggota yang setara. Uji reliabilitas kuesioner yang digunakan dalam penelitian ini adalah alpha Cronbach's dengan SPSS for windows versi 22.0. Kuesioner yang lulus uji reliabilitas adalah $\alpha>$ r. tabel. Keseluruhan pertanyaan dinyatakan reliabel dan valid (lampiran 3). Data sekunder diperoleh melalui informasi tertulis dari kantor desa, seperti profil desa, monografi, dan daftar anggota

\section{Teknik Penentuan Informan}

Data dari penelitian diperoleh dari responden dan informan. Responden dalam penelitian ini adalah seluruh anggota Kelompok Tani Bunga Desa II, Desa Sukaharja, Kecamatan Cijeruk, Kabupaten Bogor. Responden diambil menggunakan metode sensus, hal ini dikarenakan jumlah anggota yang tidak terlalu banyak, sehinga jumlah responden dalam penelitian ini adalah 30 orang. Pemilihan terhadap informan dilakukan secara sengaja (purposive) kepada tokoh masyarakat atau stakeholder terkait yang mengetahui dengan jelas mengenai Kelompok Tani Bunga Desa II diantaranya adalah kepala desa, ketua kelompok tani, serta masyarakat yang memiliki pengaruh kuat di desa tersebut. Banyaknya informan di sini tidak dibatasi, akan tetapi informan tersebut sudah dapat memberikan 
informasi yang relevan dan dapat membantu peneliti dalam menjawab perumusan masalah dalam penelitian.

\section{Teknik Pengolahan dan Analisis Data}

Penelitian ini mempunyai dua jenis data yang diolah dan dianalisis yaitu data kuantitatif dan data kualitatif. Data kuantitatif yang diperoleh dari kuesioner yang terkumpul kemudian diolah melalui Microsoft Excel 2013 dan Statistical Program for Social Sciences (SPSS version 22.0). Data kuantitatif yang didapat diuji menggunakan statistik Rank Spearman. Uji korelasi Rank Spearman digunakan untuk mengetahui hubungan antara karakteristik anggota kelompok tani dengan penggunaan media sosial whatsapp, serta hubungan antara penggunaan media sosial whatsapp dengan kohesivitas kelompok tani. Hasil uji korelasi Rank Spearman menghasilkan p-value yang menunjukkan hubungan antara variabel yang diujikan pada taraf nyata $(\alpha)=0.05$. Jika nilai $p$-value lebih kecil dari nilai taraf nyata $(\alpha)=0.05$, maka terdapat hubungan yang signifikan antar variabel yang diuji. Menurut Sugiyono dan Susanto Jika nilai koefisien korelasi berada di antara 0,00-0,199 maka tingkat hubungannya sangat lemah, nilai 0,200-0,399 memiliki arti bahwa tingkat hubungannya lemah, nilai 0,400-0,599 memiliki arti bahwa tingkat hubungannya sedang/cukup, nilai 0,600-0,799 memiliki arti bahwa tingkat hubungannya kuat, dan nilai 0,800-1,00 memiliki arti bahwa tingkat hubungannya sangat kuat.

\section{HASIL DAN PEMBAHASAN}

\section{HUBUNGAN ANTARA KARAKTERISTIK INDIVIDU DENGAN TINGKAT PENGGUNAAN WHATSAPP}

\begin{tabular}{|l|c|c|c|}
\hline \multirow{2}{*}{$\begin{array}{c}\text { Karakteristik } \\
\text { Individu }\end{array}$} & \multicolumn{3}{|c|}{ Tingkat Penggunaan } \\
\cline { 2 - 4 } & Frekuensi & Durasi & Atensi \\
\hline Usia & 0.065 & 0.197 & 0.248 \\
\hline Pendidikan & $0.464^{* *}$ & $0.419^{*}$ & 0.251 \\
\hline Skala usaha & -0.190 & 0.232 & $0.662^{* *}$ \\
\hline Pengalaman & 0.263 & 0.129 & 0.145 \\
\hline $\begin{array}{l}\text { Lama } \\
\text { bergabung }\end{array}$ & 0.008 & 0.185 & 0.404 \\
\hline
\end{tabular}

Karakteristik individu pada penelitian ini diantaranya usia, pengalaman usaha tani, lama bergabung dengan kelompok tani, tingkat pendidikan, dan skala usaha. Pada karakteristik individu tidak semua variabel memiliki hubungan yang signifikan dengan penggunaan media whatsapp yang dapat dilihat dari frekuensi, durasi, dan atensi. Hasil penelitian di lapang menunjukkan, tingkat pendidikan memiliki hubungan dengan frekuensi dan durasi penggunaan whatsapp, semakin tinggi pendidikan petani maka frekuensi dan durasi penggunaan whatsappnya juga semakin tinggi. Selanjutnya, ditemukan juga bahwa lama bergabung dan skala usaha berhubungan dengan atensi penggunaan whatsapp. Responden dengan lama bergabung tinggi cenderung memiliki atensi yang lebih terhadap kelompok tani. Hal tersebut dikarenkan mereka merasa menjadi bagian dalam pembangunan kelompok tani dan merasa bergabung dengan kelompok tani memberikan banyak manfaat dalam membantu usaha tani tanaman hias yang mereka miliki, begitu juga dengan skala usaha, semakin tinggi skala usaha maka atensi terhadap penggunaan whatsappnya semakin tinggi. 


\section{HUBUNGAN ANTARA TINGKAT PENGGUNAAN WHATSAPP DENGAN DERAJAT KOHESIVITAS KELOMPOK TANI}

\begin{tabular}{|c|c|c|c|c|c|}
\hline $\begin{array}{c}\text { Tingkat } \\
\text { Pengguna } \\
\text { an }\end{array}$ & \multicolumn{5}{|c|}{ Kohesivitas Kelompok } \\
\cline { 2 - 6 } & KI & KK & K T & KKJ & T \\
\hline Frekuensi & $\begin{array}{c}0.14 \\
3\end{array}$ & $\begin{array}{c}0.14 \\
2\end{array}$ & - & - & - \\
\hline Durasi & $\begin{array}{c}- \\
0.15 \\
0\end{array}$ & $\begin{array}{c}0.13 \\
0\end{array}$ & 0.082 & - & - \\
\hline Atensi & $\begin{array}{c}0.38 \\
2^{*}\end{array}$ & $\begin{array}{c}0.26 \\
9\end{array}$ & $\begin{array}{c}0.543 \\
* *\end{array}$ & 0.192 \\
\hline$*$ & 0.110 & 0.641 \\
$*$
\end{tabular}

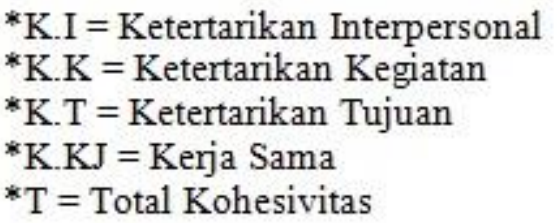

Hubungan tingkat penggunaan whatsapp (frekuensi, durasi, dan atensi) dengan kohesivitas kelompok tani memiliki hasil yang berbeda. Tidak terdapat hubungan antara frekuensi dan durasi terhadap kohesivitas kelompok tani yang dilihat dari ketertarikan interpersonal, ketertarikan pada kegiatan, ketertarikan pada tujuan, dan kerja sama. Sedangkan pada bagian atensi penggunaan whatsapp, terdapat hubungan dengan kohesivitas kelompok tani. Hubungan atensi dengan ketertarikan interpersonal, dan ketertarikan pada kegiatan termasuk kategori rendah, sedangkan hubungan atensi dengan ketertarikan pada tujuan dan kerja sama termasuk kategori kuat dan signifikan. Sehingga, semakin anggota kelompok tani memberikan perhatiannya terhadap anggota kelompok tani yang lain, maka dapat meningkatkan kohesivitas di dalam kelompok tani.

\section{KESIMPULAN}

(1) Anggota Kelompok Tani Bunga Desa II memiliki karakteristik individu yang berbeda-beda. Pada faktor karakteristik usia dan pengalaman usaha tani, tidak ditemukan hubungan nyata dengan dengan penggunaan whatsapp baik dari frekuensi, durasi, dan atensi. Faktor tingkat pendidikan memiliki hubungan nyata dengan frekuensi dan durasi penggunaan whatsapp tetapi tidak memiliki hubungan nyata dengan atensi penggunaan whatsapp, atensi penggunaan whatsapp hanya memiliki hubungan nyata dengan lama bergabung dan skala usaha tani; (2) Tidak semua faktor penggunaan whatsapp memiliki hubungan nyata dengan derajat kohesivitas. Frekuensi dan durasi tidak memiliki hubungan nyata denga derajat kohesivitas kelompok tani, hanya atensi yang memiliki hubungan nyata dengan derajat kohesivitas kelompok tani baik itu dari ketertarikan interpersonal, ketertarikan pada kegiatan, ketertarikan pada tujuan, dan kerja sama antar anggota kelompok tani. Hal ini dapat menunjukkan bahwa semakin tinggi atensi yang diberikan anggota terhadap anggota lainnya, maka semakin tinggi kohesivitas anggota Kelompok Tani Bunga Desa II.

\section{Saran}

Berdasarkan hasil penelitian ini dapat disarankan: (1) Bagi akademisi, penelitian selanjutnya disarankan untuk mengkaji lebih lanjut mengenai hubungan penggunaan media sosial lainnya selain whatsapp dengan kohesivitas kelompok tani, serta bagaimana dampaknya terhadap kehidupan pertanian; dan (2) Bagi Kelompok Tani Bunga Desa II adalah melakukan komunikasi yang lebih terbuka terhadap anggota lainnya karena keterbukaan dapat membuat kelompok semakin kompak dan tidak terjadi kesenjangan informasi antar anggota. Selain hal tersebut, kelompok juga diharapkan dapat melakukan pertemuan rutin yang lebih terjadwal. Hal ini berguna untuk memotivasi anggota untuk semakin memajukan dan mengembangkan kelompok serta dapat 
saling memahami keadaan internal ataupun masalah yang terjadi di dalam kelompok, serta dapat meningkatkan kepedulian antar anggota kelompok.

\section{DAFTAR PUSTAKA}

[BPS]. Badan Pusat Statistik. 2018. Statistik Mata Pencaharian. [internet]. [diunduh tanggal 1 Januari 2020]. Dapat diunduh di: www.bps.go.id

APJII. 2018. Indonesia internet users. Laporan asosiasi penyelenggara jasa internet Indonesia. [internet]. [diunduh pada tanggal 2019 Mei 03]. Tersedia pada : https://apjii.or.id/content/read/39/27/PROFIL-PENGGUNAINTERNET-INDONESIA2017

Ardiyanto, Erdinaya. 2005. Komunikasi Massa: Suatu Pengantar. [buku]. [diunduh pada 27 Agustus 2019]. Dapat diakses pada : http://e-journal.uajy.ac.id/4721/1/JURNAL.pdf Munandar AS. 2001. Psikologi Industri dan Organisasi. Jakarta (ID): UI-Press

Baron, Byrne. 2003. Psikologi sosial. Jakarta (ID): Erlangga

Beebe SA, Masterson JT. 1994. Communicating in Small Groups: Principles and Practices. New York (US): HarperCollins College Publisher.

Benu M, Mamahit Y, dan Wangke WM. 2016. Kajian modal sosial pada kelompok tani Di Desa Tumani Kecamatan Maesaan Kabupaten Minahasa Selatan (Kelompok Tani Esa Waya dan Kelompok Tani Sinar Mas). Jurnal Agri-Sosio. [Internet]. [Diunduh pada 13 Juli 2019]; Vol 3(02): Universitas Sam Ratulangi. Manado (ID). Dapat di unduh: https://media.neliti.com/media/publications/76145-ID-kajian-modal-sosial-padakelompok-tani-d.pdf

Mislini. 2006. Analisis Jaringan Komunikasi pada Kelompok Swadaya Masyarakat. Kasus KSM di Desa Taman Sari Kabupaten Bogor, Provinsi Jawa Barat. [tesis]. Bogor (ID) : Institut Pertanian Bogor.

Nasrullah R. 2015. Media Sosial Perspektif Komunikasi, Budaya, dan Sosioteknologi. [buku]. [diunduh pada 2 Juli 2019]. Tersedia pada https://openlibrary.telkomuniversity.ac.id/pustaka/103810/media-sosial-perspektifkomunikasi-budaya-dan-sosioteknologi.html

Noorlam GI. 2015. Kohesivitas Kelompok dalam Komunitas Virtual Kaskus Regional Malang. Jurnal Kom Sains. [diunduh 2019 Februari 20]. Vol. 2(3). Hal 1-10. Malang [ID]. Dapat diunduh dari: https://www.academia.edu/12568804/KOHESIVITAS_KELOMPOK_DALAM_KOMU NITAS_VIRTUAL_STUDI_DESKRIPTIF_KUALITATIF_TERHADAP_KOMUNITA S_ONLINE_KASKUS_REGIONAL_MALANG

Peraturan Menteri Pertanian Nomor 273 Tahun 2007.Tentang Pedoman Pembinaan Kelompok Tani dan Gabungan Kelompok Tani. BKP5K Kabupaten Bogor(ID). Tersedia pada : http://eprints.upnyk.ac.id/13799/1/Prosiding\%20Seminar\%20Nasional\%20FP\%20UNIG AL\%201\%20April\%202017.pdf

Rakhmat J. 2005. Metode Penelitian Komunikasi. Bandung (ID): PT Remaja Rosdakarya.

Ratnasari A. 2007. Pengaruh Komunikasi Antarpribadi Bermedia Internet Terhadap Persahabatan Mahasiswa Di Dunia Maya. Jurnal MediaTor. [Internet]. [diunduh 2019 Juli 11]. Vol. 8(1) Hal $166 \quad-\quad 182 . \quad$ Jakarta [ID]. Dapat diunduh dari:https://ejournal.unisba.ac.id/index.php/mediator/article/download/1236/799\&prev=se $\operatorname{arch}$

Robbins. 1999. Prinsip-prinsip Perilaku Organisasi. Edisi ke 5. Jakarta (ID): Erlangga

Sukrillah A. Ratnamulyani IA. Kusumadinata AA. 2017. Pemanfaatan Media Sosial Melalui Whatsapp Group Fei Sebagai Sarana Komunikasi. Jurnal Komunikatio. [Internet]. [diunduh pada 6 Juni 2019]. Vol 03(2). Hal 95-104. Bogor:(ID). Dapat diunduh pada : https://www.researchgate.net/publication/324629426_PEMANFAATAN_MEDIA_SOSI AL_MELALUI_WHATSAPP_GROUP_FEI_SEBAGAI_SARANA_KOMUNIKASI

Sulistiawati A, Lubis DP, Mulyani ES. 2014. Analisis Jaringan Sosial dalam Gabungan Kelompok Tani (Gapoktan) Tani Berkah. Jurnal Sodality. [Internet].[diunduh pada 9 Juni 2019]. Vol. 
02(2). Hal.76-82. Bogor (ID). Dapat diunduh pada : https://journal.ipb.ac.id/index.php/sodality/article/viewFile/9415/7378

We are social. 2019. Indonesian Digital Report 2019. [diakses 6 Juni 2019]. Tersedia pada : https://wearesocial.com/global-digital-report-2019

Whatsapp inc. 2018. Whatsapp Messenger. [di akses 2 Juli 2019]. Tersedia pada: https://itunes.apple.com/id/app/whatsappmessenger/id310633997?l=id\&mt=8

Wulansari H, Hardjajani T, Nugroho A. (2013). Hubungan antara Komunikasi yang Efektif dan Harga Diri dengan Kohesivitas Kelompok pada Pasukan Suporter Solo Sejati (Pasoepati). [diakses $\operatorname{tgl} 20$ Januari 2020]. Tersedia pada: https://www.academia.edu/9272088/Wulansari_et_al_HUBUNGAN_ANTARA_KOMU NIKASI_YANG_EFEKTIF

Yuvaraj. 2012. Making the Case for Social Computing. [diunduh 2019 Maret 17. ]. Dapat diakses di: $\quad$ http://www.cognizant.ch/InsightsWhitepapers/Making-the-Case-forSocialComputing.pdf 